\title{
Indigenous marine resource management on the Northwest Coast of North America
}

\author{
Dana Lepofsky ${ }^{1 *+}$ and Megan Caldwell ${ }^{2+}$
}

\begin{abstract}
There is increasing recognition among anthropologists that indigenous peoples of the Northwest Coast actively managed their terrestrial and marine resources and ecosystems. Such management practices ensured the ongoing productivity of valued resources and were embedded in a complex web of socio-economic interactions. Using ethnographic and archaeological data, this paper synthesizes the ecological and cultural aspects of marine management systems of coastal First Nations. We divide our discussion into four aspects of traditional management systems: harvesting methods, enhancement strategies, tenure systems, and worldview and social relations. The ethnographic data, including memories of living knowledge holders, tend to provide windows into daily actions and the more intangible aspects of management; the archaeological record provides insights into the more tangible aspects and how management systems developed through time and space. This review demonstrates not only the breadth of Northwest Coast marine management but also the value of integrating different kinds of knowledge and data to more fully document the whole of these ancient management systems.
\end{abstract}

Keywords: Northwest Coast First Nations, Marine resource management, Harvesting methods, Tenure, Worldview, Traditional ecological knowledge

\section{Review}

For decades, anthropologists, including archaeologists, have struggled to come up with classificatory schemes that would describe how subsistence-based peoples interact with their environments (e.g., Ford 1985; Harris 1989, 1996; Smith 2001). These discussions emerged out of the realization that traditional peoples worldwide rarely rely solely on truly wild or domesticated resources. Rather, there are continua of human-environmental interactions that encompass differing degrees of human management of their environment (Fowler and Lepofsky 2011).

With a few notable exceptions (e.g., Croes and Hackenberger 1989; Johannes 1981, 1982; Smith 2011a; Thornton and Scheer 2012; Turner 2005), most of the discussions about traditional management practices have revolved around human interactions with the plant world. On the Northwest Coast of North America, there

\footnotetext{
* Correspondence: dlepofsk@sfu.ca

${ }^{\dagger}$ Equal contributors

${ }^{1}$ Department of Archaeology, Simon Fraser University, Burnaby, BC V5A 1S6,

Canada

Full list of author information is available at the end of the article
}

have been significant strides in the last decade to firmly establish in the anthropological literature the central role of plant management in the ancient and traditional subsistence practices of coastal First Nations. Extensive research with traditional knowledge holders, and to a lesser extent with archaeological and paleoecological records, demonstrates the widespread management of plants at both individual and ecosystem levels (e.g., Deur and Turner 2005; Thornton 1999; Weiser and Lepofsky 2009).

In part spurred on by evidence of traditional plant management practices, regional ethnobiologists, working with traditional ecological knowledge holders, have documented parallel management practices in marine resources and ecosystems (Hunn et al. 2003; Langdon 2006a, 2006b; Thornton et al. 2010a, 2010b). That such practices were widespread in the past is not surprising given the fundamental importance of marine resources in the lives of Northwest Coast peoples (Newton and Moss 2005; Ellis and Swan 1981; Ellis and Wilson 1981; Moss 1993).

Archaeologists have been slower to embrace the idea of marine resource management on the Northwest Coast, and in particular that management systems played a 
role in ensuring ongoing access and availability of resources. In the case of salmon, for instance, many recognize the combined importance of mass capture and storage technologies but emphasize the role that social networks had on dampening spatial and temporal resource variability (Schalk 1977; Suttles 1987). In the case of shellfish, Croes and Hackenberger $(1988,1989)$ posit that overexploitation led to the development of harvest controls, but they do not recognize the possibility of enhancement strategies. The lack of recognition of the breadth of management strategies is in part due to the fact that the archaeological record, because it is largely an amalgamation of certain kinds of events, does not often provide evidence of the subtle management practices that may mimic natural processes (e.g., transplanting fish eggs) or that are conducted by individuals (Lepofsky and Kahn 2011).

The nature of archaeological discussions about marine resource management have changed in recent years, in part prompted by the growing body of literature on ancient plant management and also on the relatively recent recognition by archaeologists of ancient features that were undeniably used to manage clams ("clam gardens", see below). These recent discussions are notable because they combine archaeological and traditional knowledge and because they seek to place traditional marine management within its larger socio-economic context (e.g., Caldwell et al. 2012; Campbell and Butler 2010; Groesbeck 2013; Powell 2012; White 2006).

Here, we synthesize the vast body of disparate archaeological and ethnographic information, including currently held knowledge, on marine management by Northwest Coast peoples to better situate these traditional practices within the larger continuum of Northwest Coast management systems. We include in our review the management of all marine resources and their ecosystems, including that of the anadromous salmon. We use the term management here to refer to any conscious choices made about plant and animal use that could influence the resource (Lertzman 2009) and include in our discussion both tangible and intangible aspects of this management. As with today's resource management, our definition makes no assumption about whether the management results in positive or negative outcomes (c.f. Lertzman 2009), although we recognize that many management practices resulted in sustained or increased diversity and/ or yields. Following Turner and Berkes (2006), the discussion is organized around four aspects of traditional management systems: harvesting methods, enhancement strategies, tenure systems, and worldviews and social relations. This review demonstrates not only the breadth of Northwest Coast marine management but also the value of integrating different kinds of knowledge and data to more fully document the whole of these ancient management systems.

\section{Social and ecological context of Northwest Coast marine management}

The Northwest Coast region (Figure 1) is widely known for its abundant marine life. This abundance has been central to the lives of coastal peoples since the region was first colonized in the early Holocene (e.g., Cannon and Yang 2006; Wigen 2005; Ames and Maschner 1999). Archaeological and ethnographic literature document the wide range of marine animal taxa on which Northwest Coast peoples relied. In addition to a few focal taxa such as Pacific salmon (Oncorhynchus spp.), Pacific herring (Clupea pallasii), rockfish (Sebastes spp.), and halibut (Hippoglossus stenolepis), a wide variety of marine fish, shellfish, and sea mammals were eaten. Archaeological and ethnographic evidence suggests local availability influenced what species of fish and shellfish were used and preferred in any given place (Cannon et al. 2011; Lepofsky et al. 2007; Losey et al. 2004; McKechnie 2005; Monks 2011; Orchard 2007; Pierson 2011).

Age, gender, and status influenced the ways in which individuals participated in the management and procurement of marine resources on the Northwest Coast. Although roles were not rigidly defined (Ellis and Swan 1981; Moss 1993), ethnographic sources suggest that men constructed fish traps and wove nets (e.g., Miller and Seaburg 1990), hunted sea mammals (e.g., Drucker 1951), and fished. Women and young children collected shellfish, and processed fish and sea mammals procured by men (e.g., Drucker 1951). Slaves, who were considered genderless, could be called on to do any task (Donald 1997), such as when large numbers of fish had to be processed. Conversely, some tasks, such as the procurement of whales and other large sea mammals, were restricted to high status males (e.g., Drucker 1951), and the elite might control access to fish weirs (Gunther 1927), with rights of first harvest. Importantly, all of these tasks were embedded in community-specific cultural practices and beliefs, such as participation in First Salmon ceremonies (e.g., Amoss 1987; Gunther 1927; Kennedy and Bouchard 1983).

\section{Marine resource management on the Northwest Coast}

The following discussion of Northwest Coast marine management encompasses both ethnographic and archaeological information (Table 1). Ethnographic and ethnohistoric sources, although suffering from issues of bias (e.g., Moss 1993), provide good baseline information on management technologies and practices at and just after contact. The ethnographic data used in this review were written during vastly different times. Early ethnographic sources (i.e., prior to 1970) overwhelmingly 


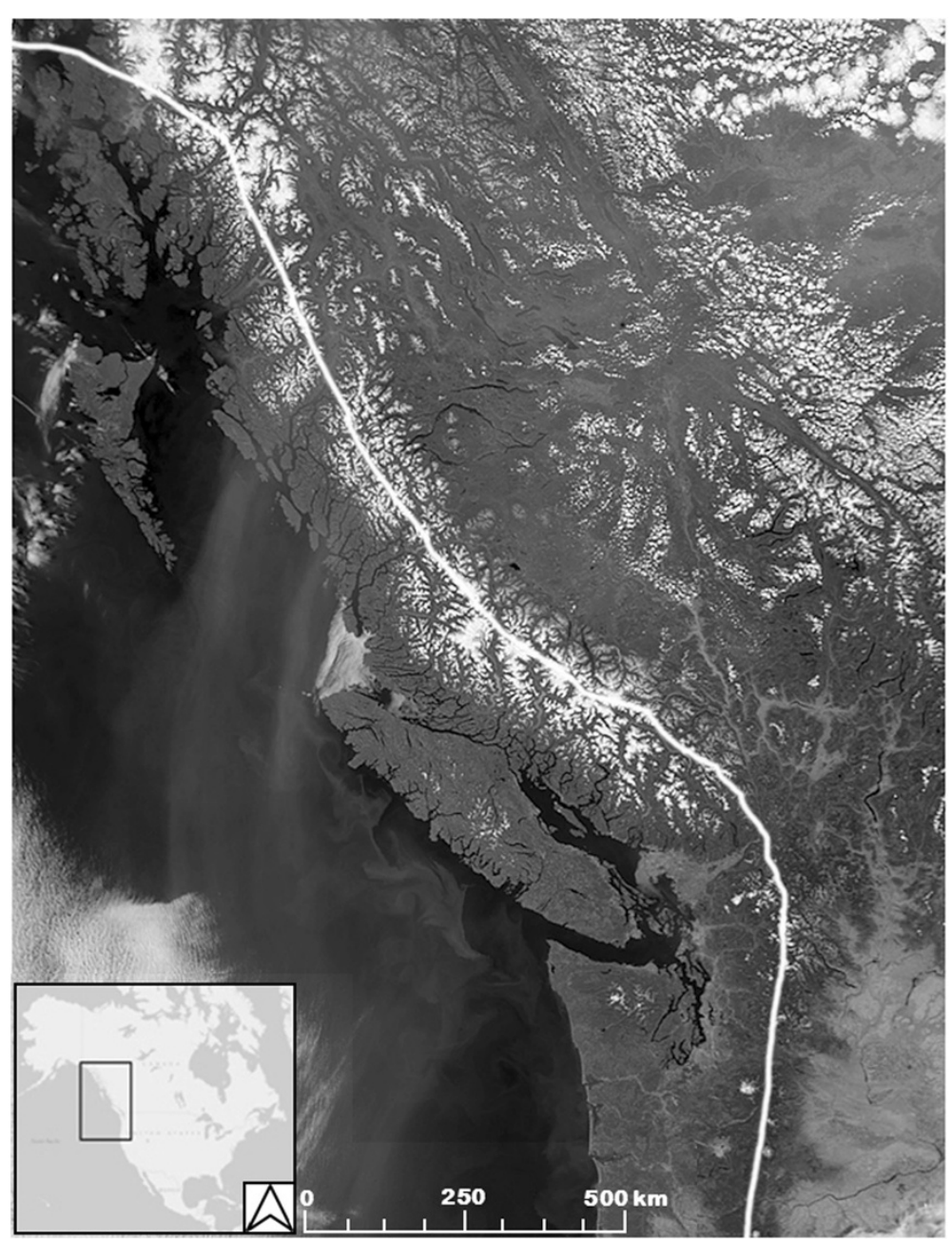

Figure 1 Northwest Coast of North America (image adapted from NASA/Earth Observatory: http://visibleearth.nasa.gov/view.php?

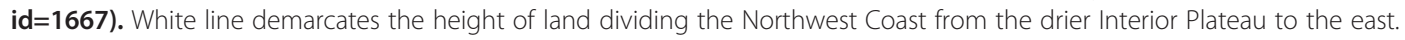

consist of trait lists and descriptions of technologies. Although there is little consideration of tenure systems and aspects of worldviews and social relations in these early ethnographic sources, there are nuggets of information about management and tenure that reflect the time depth of these practices (e.g., Drucker 1951; Stern 1934). More recent ethnographic sources, and especially those that rely on first hand knowledge and experience (e.g., Turner et al. 2013; Ellis and Swan 1981; Ellis and Wilson 1981; White 2006, 2011), are more likely to contain descriptions about the various components of the whole resource management system.

Archaeological data complement well the ethnographic sources. Although the archaeological record more reluctantly reveals details about some aspects of management systems, it does provide a deep time perspective on physical details such as the timing and location of specific harvesting methods and enhancement strategies. These data, when combined with data on settlement patterns, in turn allow inferences about aspects of land tenure and social relations of ancient resource management systems.

Although we divide our review into four aspects of management (harvesting methods, enhancement strategies, tenure, and worldview; Table 1), we recognize that these categories are simply heuristic devices, and actions placed in one category could easily fit in another. For instance, some aspects of harvesting, such as size selection via nets, could be discussed with enhancement methods or with a discussion of harvesting restrictions and tenure. The very nature of traditional management systems is that they are an integrated whole which cannot be easily segmented into component parts.

\section{Harvesting methods}

Various social and economic decisions are embedded within the choice to use different resource harvesting methods. Fish and sea mammals were harvested 
Table 1 Components of marine resource and environmental management systems on the Northwest Coast

\begin{tabular}{|c|c|c|c|}
\hline Component & Goal/intent & Strategy & Archaeological evidence of goal/intent \\
\hline \multirow{5}{*}{$\begin{array}{l}\text { Harvesting } \\
\text { methods }\end{array}$} & \multirow[t]{4}{*}{ - Selection for species and size } & - Mesh size & \multirow{4}{*}{$\begin{array}{l}\text { - Relative abundance of zooarchaeological } \\
\text { taxa; size of zooarchaeological taxa }\end{array}$} \\
\hline & & - Capture method & \\
\hline & & • Timing & \\
\hline & & - Location & \\
\hline & - Extending harvests & - Habitat creation & • Holding ponds \\
\hline \multirow{3}{*}{$\begin{array}{l}\text { Enhancement } \\
\text { strategies }\end{array}$} & \multirow[t]{2}{*}{ - Increasing availability/abundance } & - Transplanting eggs & • None \\
\hline & & • Habitat manipulation \& extension & - Beaches cleared of stone; intertidal walls \\
\hline & - Selection for age/size of resource & - Return young/small bivalves to beach & - Age and size of zooarchaeological taxa \\
\hline \multirow{6}{*}{ Tenure systems } & \multirow{3}{*}{$\begin{array}{l}\text { - Limit/control access to resources } \\
\text { and harvesting locations }\end{array}$} & - Rights to harvest specific species & \multirow{3}{*}{$\begin{array}{l}\text { - Differences in zooarchaeological taxa } \\
\text { between sites; rock art marking fishing locales; } \\
\text { management features in proximity to settlements }\end{array}$} \\
\hline & & - Ownership of harvesting locales & \\
\hline & & $\begin{array}{l}\text { - Ownership and control of harvesting } \\
\text { features }\end{array}$ & \\
\hline & \multirow[t]{3}{*}{ - Proscriptions on harvesting } & - Restricted timing/season & \multirow{3}{*}{$\begin{array}{l}\text { - Relative abundance \& size of } \\
\text { zooarchaeological taxa }\end{array}$} \\
\hline & & - Limits on catch size & \\
\hline & & - Limits on who can harvest & \\
\hline \multirow{4}{*}{$\begin{array}{l}\text { World view and } \\
\text { social relations }\end{array}$} & - Respect for non-human kin & - Do not take more than is needed & - Sustained use over millennia \\
\hline & \multirow[t]{2}{*}{ - Ritual connections to animal world } & • First food ceremonies (e.g., salmon) & - Differential abundances of salmon to other taxa \\
\hline & & - Return remains to water & - None \\
\hline & - Maintenance of kinship ties & - Feasting, trading, social events & - Extra-local taxa in shell middens \\
\hline
\end{tabular}

individually using a variety of methods, such as harpoons, gaff hooks, and hook and line. In addition, and of central importance to the development of the region's large and complex societies, Northwest Coast peoples harvested fish en masse using a variety of weirs, traps, and nets (Figure 2). Clams were harvested with digging sticks.

Choice of net size and mesh regulated the overall size of the catch, the species caught, and the size and age of the individuals harvested. Detailed ethnographic accounts as well as waterlogged archaeological deposits (Figure 3) indicate a wide variety of net types were used on their own, and as parts of traps and weirs. Net meshes, which regulated the size and species of the fish caught, were standardized by using net gauges. Examples of net gauges have been recorded in both the ethnographic (e.g., Duff 1952; Haeberlin and Gunther 1930; Stewart 1977) and archaeological (e. g., Bernick 1989; Borden 1976; Croes 1995; Munsell 1976) records.

A variety of management decisions influenced the timing and length of harvests. Drucker (1951) writes that on the west coast of Vancouver Island, herring were known to spawn sequentially in neighboring coves, and so the timing of herring egg harvest was different for each cove. As well, a combination of archaeological and ethnographic information indicates that harvest times were extended through the construction of holding ponds built into intertidal fish traps (e.g., White 2011; Lepofsky 2005; Caldwell et al. 2012) (Figure 4). By keeping the fish alive through multiple tidal cycles, these ponds extended the period in which fish could be killed and processed. Decisions such as when to open or close weirs, and when to dismantle portions of traps likewise determined the timing of harvests (Figure 5) (c.f., Losey 2010). Decisions by downriver settlements about how many fish to harvest and when to open weirs would have had a significant impact on the nature and timing of the resource for upriver peoples (c.f., Swezey and Heizer 1977).

The ethnographic and archaeological records are somewhat divergent with regards to people's decisions about the number and kind of taxa harvested from weirs and traps. That is, most ethnographic sources describe the targeting of single fish species, especially salmon (e.g., White 2006, Drucker 1951), as well as attracting seals and other fish predators (Barnett 1955; Elmendorf 1992). In contrast, the zooarchaeological record recovered from middens suggests these features trapped a wide range of predator and prey species (e.g., Monks 1987). This discrepancy between the two records can in part be accounted for by the fact that ethnographic accounts tend to capture specific events, whereas archaeological records are palimpsests of events. On the flip side, our interviews with Tla'amin knowledge holders demonstrate that ethnographic information can 


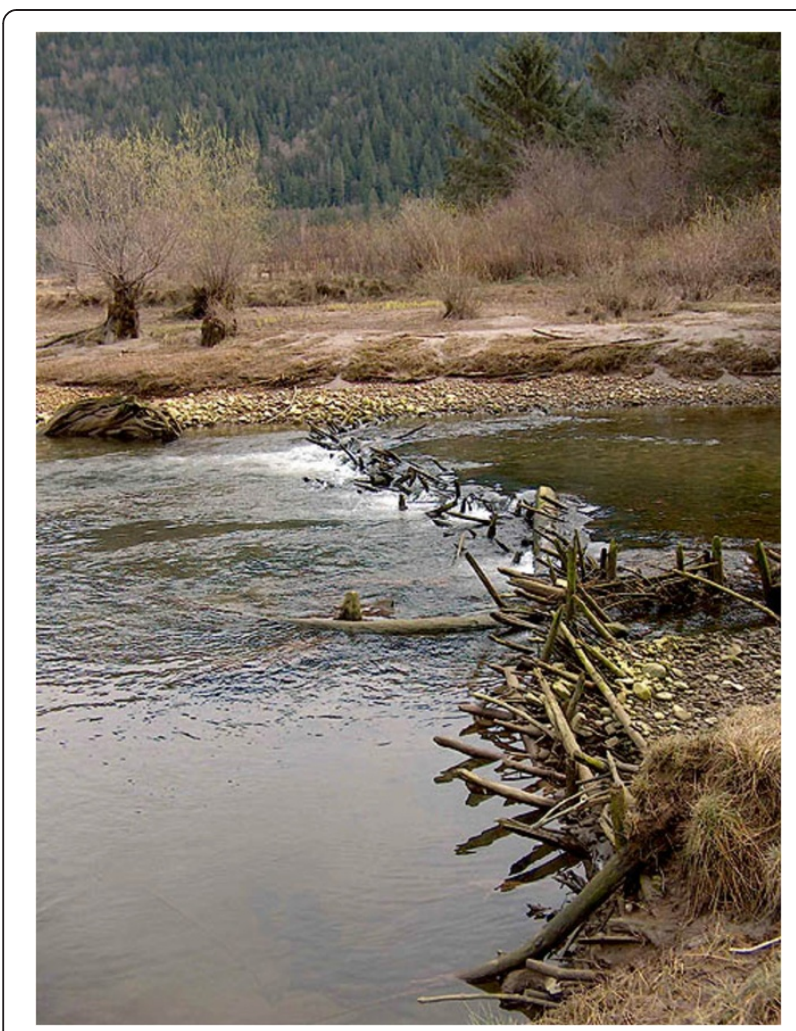

Figure 2 Approximately 200-year-old wooden riverine fish weir in South Bentick Arm, Central Coast, B.C. This was likely used to trap salmon by impeding their movement upstream. (Photo: courtesy of Alan Hobler).

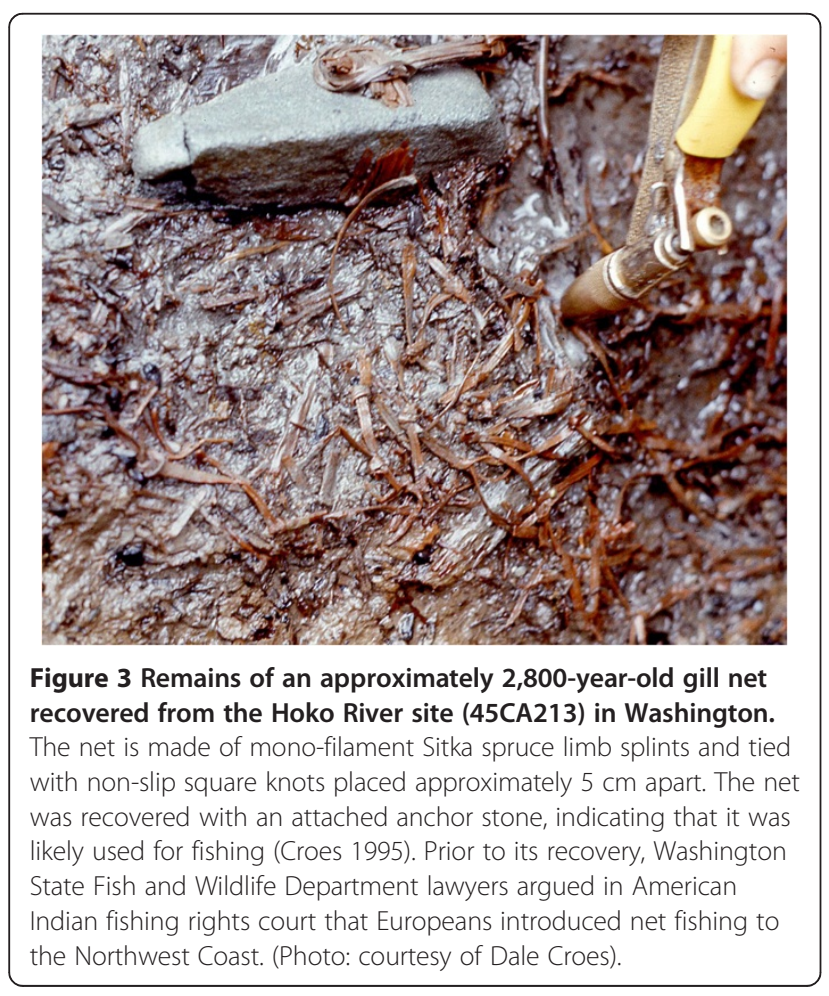

sometimes provide information on the harvest of taxa that are rarely preserved in archaeological contexts (e.g., Pacific octopus [Enteroctopus dofleini] and sea cucumbers [Parastichopus californicus]).

Ethnographic information suggests a variety of other harvesting rules protected resources from being overharvested. Harvesting rules include controlling the number and timing of seabird eggs harvested (Hunn et al. 2003), allowing some kelp fronds with herring eggs to remain unharvested so the eggs could hatch (Steven Carpenter, pers. comm. to D. Lepofsky), and delaying the harvest of herring until after spawning (Michelle Washington, pers. comm. to D. Lepofsky).

The archaeological record is less forthcoming about whether harvesting rules were designed to prevent overharvesting. For instance, although Lyman (2003) noted that the capture of predominantly adult male Steller sea lions in Oregon likely prevented depletion of the local sea lion population, he questions the intentionality of this behavior. We would suggest that whether such behaviors were initiated with conservation in mind is a moot point. Rather, a likely scenario is that the people who relied on these resources, and who closely watched animal behavior, understood the consequences of their actions. Furthermore, as demonstrated by the discussion of clam harvesting below, measurements of archaeological clams indicate intentional harvesting practices in the past.

\section{Enhancement strategies}

Enhancing local environments to increase availability or productivity, or to make resources more reliable, is a well-established component of traditional management systems worldwide (Fowler and Lepofsky 2011). Recently, Smith (e.g., Smith 2011a, 2011b) situated these behaviours within an evolutionary framework that views tangible management practices as aspects of niche construction. Some of the marine resource enhancement strategies discussed here can be viewed as examples of people creating niches that served to increase availability and productivity and in some instances to make resources more reliable.

The ethnographic literature provides numerous examples of Northwest Coast peoples applying management techniques to sustain and/or enhance the availability of salmon and herring. For instance, people transplanted herring and salmon eggs and created spawning populations in areas where the original population was decimated or where there was no prior spawning population (Carpenter et al. 2000; Jones 2002; Kennedy and Bouchard 1983; Langdon 2006b; Sproat 1868; Thornton et al. 2010b). In southeastern Alaska, the Tlingit took care to remove beaver dams on rivers as these dams would block access of sockeye (Oncorhynchus nerka) and coho (Oncorhynchus kisutch) salmon 


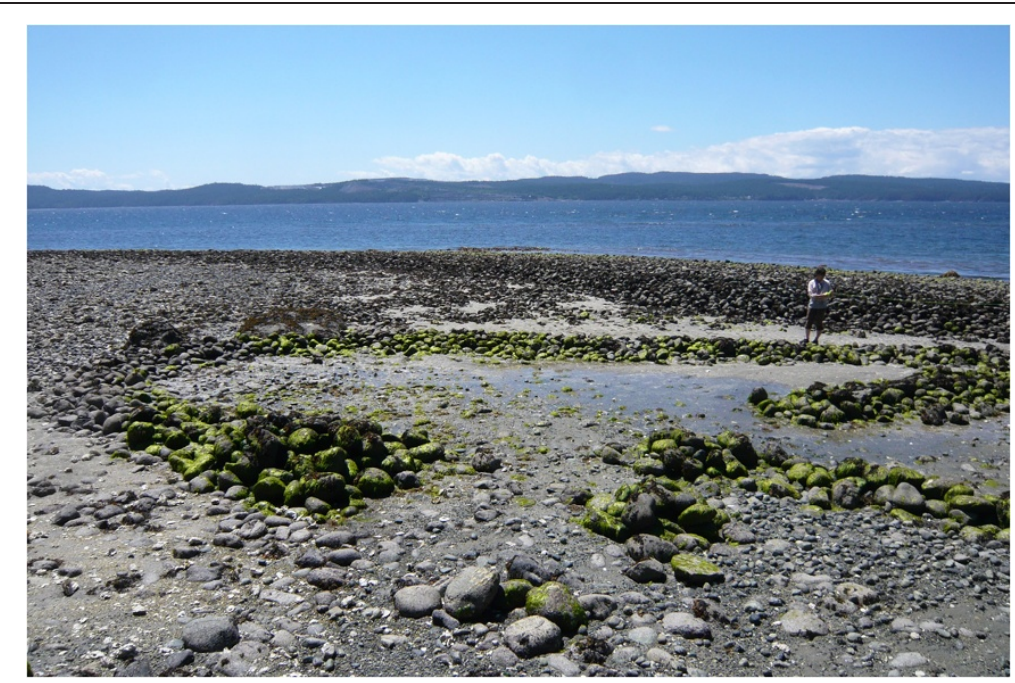

Figure 4 Hook-shaped stone intertidal fish trap near Powell River, B.C. that functioned by funneling and then trapping fish, such as herring and perch, in through the wall openings during a receding tide. Water held by the walls through the tidal sequence may have extended harvesting times. (Photo: Megan Caldwell).

to their spawning grounds further upriver (Langdon 2006b). Additionally, the Tlingit would rearrange rocks to improve stream flow and increase salmon spawning habitat; these same "streamscaping" actions would also improve visibility for salmon gaffing (Langdon 2006b). Notably, none of these behaviors will be detectable in the archaeological record.

Both the ethnographic and archaeological records demonstrate that Northwest Coast peoples used a variety of techniques to enhance clam production. In addition to the ecological benefits of aerating the beach sediments while harvesting clams, people harvesting clams recognize the benefits of returning broken shells and gravels to the beach to keep the sediments productive (Nathan Cardinal and Nicole Smith, pers. comm. to M. Caldwell). Measurements of archaeological clam shells suggest that in some cases only clams of a certain size (age) were collected and that it is possible that clam beds were left fallow to allow populations to reach the harvestable size (Cannon and Burchell 2009). This

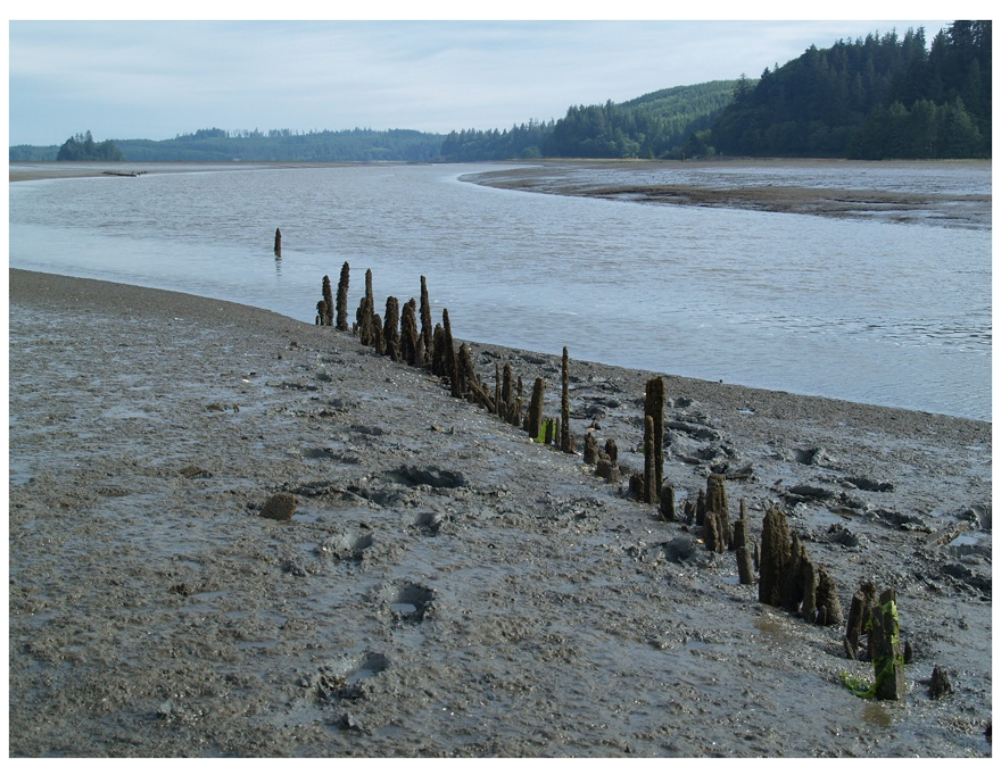

Figure 5 Wooden intertidal fish weir at Bear River, Willapa Bay, Washington. In a functional weir, stakes would run across the river channel. The absence of stakes in the channel in this feature suggests that the trap was dismantled some time in the past. Note footprints next to stakes for scale. (Photo: courtesy of Robert Losey). 
proposition is supported by traditional knowledge which states that selective harvesting left behind small clams "to keep the populations productive" (Turner 2005). In the archaeological context, we cannot know whether this size selection was a personal decision to enhance clam production because it was the "right way to behave," because of more formal harvesting and tenure rules, or simply because of a desire to eat large clams. Finally, quantification of clam size, age, and number in archaeological sites in Washington state suggests that management was occurring at the level of habitat manipulation, rather than through harvesting rules per se (Daniels 2009).

Clam gardens are a concrete archaeological example of deliberate manipulation of clam habitat to enhance production (Figure 6). These features, which are found in abundance throughout the Northwest Coast archaeological record (e.g., Harper et al. 1995, 2003), are composed of rock walls constructed in the lowest intertidal zone and tidal flats which have been cleared of boulders (Harper et al. 1995, 2003; Williams 2006; Woods and Woods 2005). Stern (1934) posited that these features increased clam harvests because it was easier to dig clams in less rocky substrates. More recent researchers have hypothesized that the stone walls trap beach sediments, thus increasing clam habitat at a specific tidal height (Harper et al. 1995). This supposition is supported by controlled ecological experiments and surveys which demonstrate higher growth rates, survivorship, densities, and biomass of clams in clam gardens than in non-walled beaches, and the connection of tidal height and slope modification to increased productivity (Groesbeck 2013).

Determining the antiquity of these rock features has been elusive. Limited archaeological research indicates that these features may be hundreds of years old (Lepofsky and Deur 2011). Across the region, it is likely that these features follow the same temporal and spatial trajectory of intertidal fish traps. That is, they have been present in some form for many millennia but have increased in abundance in the last 2,000 to 3,000 years.

In addition to these "classic clam gardens," local knowledge and the archaeological record indicate that people cleared portions of beaches to enhance production but did not necessarily build walls (Caldwell et al. 2012). Based on field observations, whether a wall was built depends on the size and slope of the beach, and the location of the sea shelf, and possibly local ecological factors. Furthermore, we note that some fish traps/holding ponds are cleared of rocks at particular tidal heights, possibly to enhance clam production. Clearing beaches of large cobbles may increase spat recruitment but determining this requires ecological experiments. Finally, we have noted that the very building of a clam garden wall, or any intertidal or sub-tidal rock feature (e.g., the stone piles used to anchor reef nets) creates habitat for a variety of valued species, such as sea cucumbers, crabs, and small fish. Although archaeologists have largely missed these subtle manipulations of marine ecosystems, they represent an important part of ancient management systems.

\section{Tenure systems}

On the Northwest Coast, as elsewhere, traditional tenure systems are fundamental to sustained marine resource management (e.g., Johannes 1981, 1982; Haggan et al. 2006; Turner and Jones 2000; Turner 2005). Such systems of ownership were embedded in larger hereditary kin- and status-based social networks (e.g., Powell 2012; Turner et al. 2000; Turner 2005) and regulated the timing and amount of resources extracted. Tenure associated with marine resources was asserted through the ownership of fish harvesting locations (e.g. streams, dip netting rocks, fish traps/weirs, coves), the rights to catch fish from specific locations (Turner and Jones 2000),
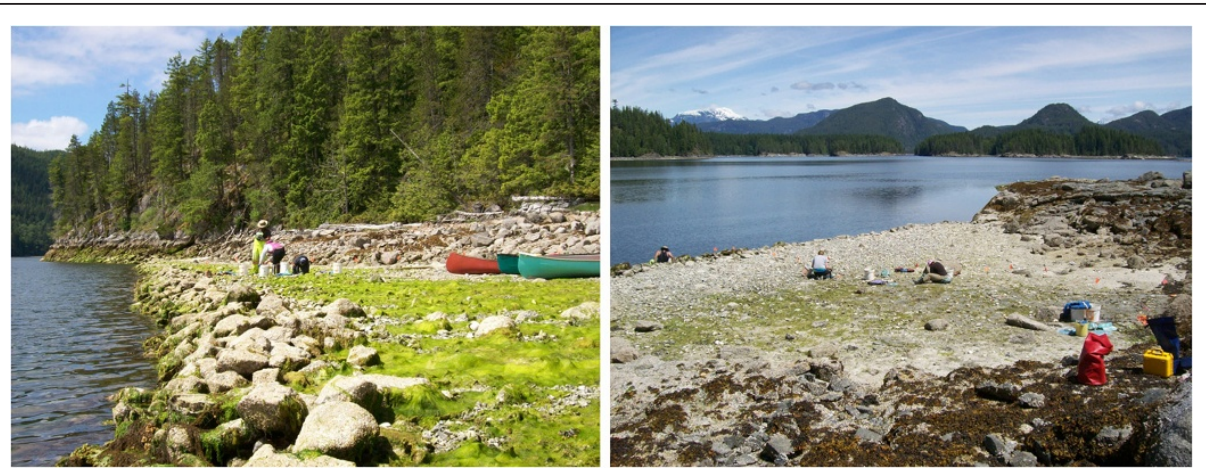

Figure 6 Clam gardens on Quadra Island, B.C. The garden is composed of a rock wall placed at the zero tide line (see wall foreground of left image, and left side of right image), which creates a flat expanse of clam habitat at an ideal tidal height. In these photos, marine ecologist Amy Groesbeck and crew are sampling clams to understand how clam garden modifications affect clam growth and development. (Photos: courtesy of Amy Groesbeck). 
when people could harvest, and who could harvest (Ramos and Mason 2004).

Claims to marine resources and ecosystems were made in a variety of ways (cf. Turner and Jones 2000). Ownership markers on the landscape, such as permanent harvesting features (fish traps, clam garden walls), cleared beaches, or now more elusive signals, such as pictographs, stories, and place names, would be known and recognized by people both within and outside of a community (Turner and Jones 2000). Access to resources could also be controlled through the use of specialized equipment (e.g., basket traps; Turner and Jones 2000) or by paying for the use of a resource by sharing the harvest with the resource's owner (Drucker 1951). At the Hoko Rockshelter in northwestern Washington, Croes (1992) suggests that a tight standard deviation around the mean age of harvested California mussels and increased use of other taxa to reduce pressure when mussel populations are stressed indicates management of the resource, possibly through territorial ownership and control over harvesting. However, Daniels (2009) argues that expanding diet breadth when high-ranked resources are stressed is an optimal foraging strategy that would not necessarily indicate active management.

In some areas of the coast, lineage-owned names were given to individual fish traps (Blackman 1990; De Laguna 1972), thus tying a lineage to the use of particular traps. The inextricable connection between lineages and resource ownership and management is also illustrated by the Tlingit "stream master," whose job it was not only to take care of salmon spawning streams, but also to manage relationships between humans and fish (Thornton 2012). At least in the post-contact era, access to a resource harvesting location was gained through permission by the owner or through marriage ties (Turner and Jones 2000). In places where weirs crossed entire rivers, blocking movement of fish, the owner of a weir would catch as much fish as needed and then open all or part of their weir to allow fish to move on to the next weir (Gunther 1927; Suttles 1955).

Classic clam gardens provide a good example of the role of permanent harvesting features in tenure systems. Stern (1934) records that a clam garden was owned by those who had cleared it; unmanaged clam beds could be used by anyone. This suggests that the act of clearing a beach, like that of clearing a camas plot or building a fish trap (Turner and Jones 2000), established some kind of claim of ownership to the clam bed. Archaeologically, the permanence and high visibility of classic clam gardens makes them ideal for assessing ancient systems of ownership.

Ancient tenure systems are detected in the archaeological record in diverse ways. Often, ownership is assumed through proximity of sites. That is, some or all of the people within the settlement closest to the resource procurement site are assumed to have controlled access to that location. The presence of a unique set of marine taxa in contemporaneous zooarchaeological assemblages can also be used to signal access to discrete, family-owned harvesting areas (Calvert 1980; McKechnie 2005). In some cases, the zooarchaeological record suggests that resources were shared among several communities living within a well-defined marine area (e.g., Lepofsky et al. 2007).

\section{Worldviews and social relations}

A significant aspect of the worldview of Northwest Coast peoples is the relationship between humans and non-human kin (e.g., Salmon People; see, e.g., Drucker 1951). By providing a framework for how to treat nonhuman kin respectfully, people were discouraged from taking more than was needed from the natural world. For example, in Heiltsuk territory on the central British Columbia coast, White (2011) notes that openings were intentionally left in fish trap walls so that fish could escape when the traps were not in use, or "gates" were opened to release the remaining fish after the trap users had taken what they needed. Archaeological examples of partially dismantled weirs may represent a similar set of protocols and beliefs (Losey 2010).

Protocols and rituals had to be followed or a resource, such as a run of fish, would fail to return in subsequent years (Jones 2002). For instance, stemming from the widespread belief that the life force of living beings is held in the bones and that life can be regenerated from the bones (Carlson 2011), many groups required that all salmon remains be returned to the water after processing. This practice ensured the return of salmon the following year (e.g., Carlson 2011; Gunther 1928; Siemthlut 2004).

Northwest Coast peoples participated in a variety of rituals that affirmed their connection to their oceanbound kin. The most widespread example is the ethnographically documented First Salmon Ceremony (Amoss 1987; Berman 2000; Gunther 1926, 1927; cf. Swezey and Heizer 1977). Some groups also celebrated the return of other important species, such as herring and eulachon, with similar ceremonies (Drucker 1955; Hamori-Torok 1990; Kennedy and Bouchard 1990); neighboring groups in California practiced the First Sea Lion Hunt (Gould 1968). Archaeological evidence for rituals in general is elusive but comes in the imagery and masks that reflect the connection among people, animals, and the spirit and tangible worlds (e.g., Carlson 2011).

Coming together for the First Salmon Ceremony, to fish communally, and to gather shellfish and other resources provided opportunities to reinforce social relations and cultural knowledge and to maintain kinship ties through feasting, trading, and other social events. 
Situating resource use within this larger social system ensured that cultural regulations were followed, that resources were tended properly, and that the system of ownership and control of resources continued (Turner and Jones 2000).

\section{Discussion}

Management of marine resources was enacted both directly through choices about when, where, and how to harvest and tend resources and indirectly through social relations and rules about the right way to behave. Collectively, the marine management system resulted in long-term sustained and sometimes enhanced production of targeted resources. Contra Alvard (1995; Alvard and Kuznar 2001), aspects of conservation embedded in Northwest Coast marine management systems can not be viewed as unintentional consequences of low population densities and simple technology. In fact, the high population densities of Northwest Coast peoples (Ubelaker 2006) made active management of marine resources even that much more important. As Anderson (1996) suggests, since technologies such as nets and traps have the potential to wipe out salmon stocks, the healthy pre-contact salmon stocks must reflect conscious choices made to preserve salmon populations. Given the fundamental importance of marine resources in the livelihoods of Northwest Coast peoples, the sheer abundance of these remains in millennia-old archaeological middens, and the well-documented aspects of terrestrial management systems, discussions of humanmarine interaction on the Northwest Coast should begin with the assumption that active management was widespread in the past.

In discussions of traditional resource management systems, the question of intentionality often arises. The issue of intention becomes particularly relevant when considering ancient management systems whose complex behaviors are usually represented by relatively simplified archaeological footprints. In our experience and that of other ethnographers on the Northwest Coast (e.g., Turner and Berkes 2006; Turner et al. 2000; Nathan Cardinal and Nicole Smith, pers. comm. to M. Caldwell), current ecological knowledge holders are well aware of the consequences of their management actions, whether played out in the physical or metaphysical realms. Widespread recognition of these tangible and intangible consequences is linked to systems of morality that dictate the "right way to behave" (Fowler and Lepofsky 2011; Reo 2011; Reo and Whyte 2011). While these rules may not be followed by all people at all times, they often play a role in people's conscious decision-making.

We can seldom know for certain if such awareness extended into pre-contact times, or whether the acts that resulted in conserving were intentional from the outset or were simply accidental byproducts of other harvesting choices (e.g., the behavior of the prey [Lyman 2003]). However, the archaeological evidence for clam management (size standardization, clam gardens, etc.) is compelling. Furthermore, indigenous peoples, because of their connections to and reliance on their natural surroundings, are often keen observers of ecological processes, and thus would have been quick to realize the benefits of their management actions (c.f., Turner and Berkes 2006). Given this, and how widespread knowledge of management was in the early contact era, the most parsimonious interpretation is that many precontact practitioners carried out management-in all its guises-with a high degree of awareness of the ways in which their actions would influence the "natural" world.

We further suggest that archaeologists sometimes stumble over the idea of intention because they fail to see the larger management system embedded within the physical remains associated with the archaeological record. For instance, a fish trap, which is what remains for archaeologists to record, is not in and of itself a management system. Rather, the use of that fish trap is embedded within a series of socio-economic actions and contexts that result in decisions about where to build the fish trap, when to use it, how much to catch, how much to release, the size of fish targeted, and who has access to the trap or net. These decisions are further embedded within larger networks of tenure, world views, and social relations that create enduring relationships among the people, resources, and the built environment.

In recognizing the extent of ancient marine management systems, we do not deny that Northwest Coast peoples sometimes negatively affected their marine environment. Given the high population numbers and complex socio-economic systems that supported and were supported by these large human populations, it would be highly surprising if humans did not have some kind of negative ecological footprint. The ecological effects of long-term efficient and extensive marine exploitation are evident in some zooarchaeological records that suggest locally depressed numbers of fish and sea mammals (Butler 2000; McKechnie 2007; Szpak et al. 2012). The extant evidence indicates that beyond these local effects, regional fish populations were consistently at high levels of abundance (Campbell and Butler 2010).

The ethnographic and archaeological records demonstrate that Northwest Coast marine management was enacted on different spatial and temporal social and ecological scales. Ecologically, resources were managed at the species level (e.g., seabird egg harvests, egg transplants, possibly clam size/age restrictions), at the level of the community (e.g., fish net sizes), and at the level of ecosystems (e.g., cleared beaches, removal of beaver 
dams). Ecosystem level management resulted in anthropogenic landscapes which attracted resources, increased and diversified habitats, and increased productivity. At social scales, management was enacted by individuals working alone and in groups and was part of daily actions and larger-scale ritual events.

These various scales of actions are not equally well represented in the ethnographic and archaeological records. Ethnographic data will always tend to highlight the more subtle, daily and often local actions involved in management and traditional ecological knowledge, whereas the archaeological record will tell the story of more dramatic landscape modifications and the cumulative actions of many events. This discrepancy between ethnographic and archaeological records is exemplified in the study of the Straits Salish reef net fishery. Based on ethnographic descriptions, we understand that this complex form of harvesting salmon involved extensive ecological knowledge which was embedded in a web of social relations, intergenerational knowledge sharing, ritual practices, and understandings of how the world works (Turner and Berkes 2006; Stewart 1977; Suttles 1974). In contrast, archaeological research on reef net fishing is limited to attempts at finding concrete evidence of this practice and dating its occurrence in the past, albeit with limited success (Boxberger 1985; Easton 1985, 1990; Moore and Mason 2011; Rozen 1981).

Considered together, the ethnographic and archaeological records provide complimentary information on traditional marine management systems. The strength of the archaeological record is that it provides tangible evidence of the deep history and evolution of resource management over time and across space. Ethnographic information, including past and present ecological knowledge, place names, and oral historical and personal stories, provides insights into the less tangible aspects of management (e.g., social relations, worldview, knowledge transmission) that are often hard to detect in the archaeological record. Sometimes, however, this information is not situated within a firm temporal framework, and changes over time can be condensed. Furthermore, whereas ethnographic information provides personal and family-based perspectives on resource management, it is less likely to inform about how management systems were enacted among multiple settlements. Thus, it is only by combining these two kinds of data and knowledge that we can fully appreciate the breadth of social, cultural, ecological, and technical contexts in which these management systems were enacted.

The value of documenting traditional marine management systems on the Northwest Coast goes well beyond recording important aspects of indigenous history. Recognizing the ecological and cultural place of these systems is linked to larger issues of indigenous rights and title, governance, and food security, as well as the value of integrating millennia-old indigenous knowledge with modern resource management. Given the coast-wide need to manage resources to sustain social and ecological resilience, it behooves us to pay careful attention to documenting this past knowledge for the future.

\section{Competing interests}

The authors declared that they have no competing interests.

\section{Authors' contributions}

$\mathrm{DL}$ conceived of the premise of the paper and drafted the manuscript. MC conducted the literature review and helped draft the manuscript. Both authors read and approved the final manuscript.

\section{Authors' information}

$\mathrm{DL}$ is a professor of Archaeology at Simon Fraser University. She is interested in the social and ecological impacts of past human interactions with their environments, particularly in the Pacific Northwest of North America. Her research program has been strengthened considerably by her collaborations with knowledge holders from diverse academic and non-academic communities.

$\mathrm{MC}$ is a PhD candidate in the Department of Anthropology at the University of Alberta. Her research examines marine resource management in Tla'amin Traditional Territory, southern British Columbia.

\section{Acknowledgements}

We thank Robert Losey for comments on an earlier version of this paper and are grateful to Ken Lertzman, Nancy Turner, and Douglas Deur for ongoing discussions about traditional resource management systems. Many thanks to Nicole Smith, Nathan Cardinal, Dale Croes, Amy Groesbeck, Robert Losey, and Alan Hobler for contributions of information and/or photographs. This research was funded in part by a SSHRC CGS Doctoral Scholarship (Caldwell).

\section{Author details}

${ }^{1}$ Department of Archaeology, Simon Fraser University, Burnaby, BC V5A 1S6, Canada. ${ }^{2}$ Department of Anthropology, University of Alberta, Edmonton, $A B$ T6G 2H4, Canada.

Received: 4 December 2012 Accepted: 21 April 2013

Published: 24 May 2013

\section{References}

Alvard M (1995) Intraspecific prey choice by Amazonian hunters. Curr Anth 36(5):789-818

Alvard M, Kuznar L (2001) Deferred harvests: the transition from hunting to animal husbandry. Am Anth 103(2):295-311

Ames KM, Maschner HDG (1999) Peoples of the northwest coast: their archaeology and prehistory. Thames and Hudson, London

Amoss PT (1987) The fish God gave us: the first salmon ceremony revived. Arctic Anth 24(1):56-66

Anderson EN (1996) Ecologies of the heart: emotion, belief, and the environment. Oxford University Press, New York

Barnett HG (1955) The Coast Salish of British Columbia. University of Oregon Press, Eugene

Berman J (2000) Red salmon and red cedar bark: another look at the nineteethcentury Kwakwaka'wakw winter ceremonial. BC Stud 125(126):53-98

Bernick K (1989) Water Hazard (DgRs 30) artifact recovery project report, permit 1988-55. Report submitted to Archaeology and Outdoor Recreation Branch, Ministry of Municipal Affairs, Recreation and Culture, Province of British Columbia, May, 1989

Blackman MB (1990) Haida: traditional culture. In: Suttles W (ed) Handbook of North American Indians, vol 7, Northwest Coast. Smithsonian Institution, Washington DC, pp 240-260

Borden CE (1976) A water-saturated site on the southern mainland coast of British Columbia. In: Croes DR (ed) The excavation of water-saturated archaeological sites (wet sites) on the northwest coast of North America, National Museum of Man Mercury Series, Archaeological Survey of Canada, paper no. 50. National Museums of Canada, Ottawa, pp 233-260 
Boxberger DL (1985) A preliminary underwater survey of Legoe Bay, Lummi Island, Washington. Int J Naut Archaeol Underw Explor 14(3):211-216

Butler V (2000) Resource depression on the northwest coast of North America. Antiquity 74:649-661

Caldwell M, Lepofsky D, Combes G, Washington M, Welch JR, Harper JR (2012) A bird's eye view of Northern Coast Salish intertidal resource management features. J Island Coastal Arch 7(2):219-233

Calvert SG (1980) A cultural analysis of faunal remains from three archaeological sites in Hesquiat Harbour. University of British Columbia, Vancouver, B.C. PhD Dissertation

Campbell SK, Butler VL (2010) Archaeological evidence for resilience of Pacific Northwest salmon populations and the socioecological system over the last 7,500 years. Ecol Soc 15(1):17

Cannon A, Burchell M (2009) Clam growth-stage profiles as a measure of harvest intensity and resource management on the central coast of British Columbia. J Arch Sci 36:1050-1060

Cannon A, Yang D (2006) Early storage and sedentism on the Pacific northwest coast: ancient DNA analysis of salmon remains from Namu, British Columbia. Am Antiquity 71(1):123-140

Cannon A, Yang D, Speller C (2011) Site-specific salmon fisheries on the central coast of British Columbia. In: Moss ML, Cannon A (eds) The archaeology of north Pacific fisheries. University of Alaska Press, Fairbanks

Carlson RL (2011) The religious system of the northwest coast of North America. In: Insoll T (ed) The Oxford handbook of the archaeology of ritual and religion. Oxford University Press, Oxford

Carpenter J, Humchitt C, Eldridge M (2000) Final report, Fisheries Renewal BC Research Reward, Science Council of BC, reference number FS99-32, Heiltsuk Cultural Education Centre, July 2000. Unpublished manuscript on file at the Heiltsuk Cultural Education Centre. Bella Bella, BC

Croes DR (1992) Exploring prehistoric subsistence change on the Northwest Coast. Res Eco Anth, Supp 6:337-366.

Croes DR (1995) The Hoko River archaeological site complex: the wet/dry site (45CA213), 3,000-1,700 B.P. Washington State University Press, Pullman

Croes DR, Hackenberger S (1988) Hoko River archaeological complex: modeling prehistoric Northwest Coast economic evolution. Res Econ Anthropol Supp 3:19-85

Croes DR, Hackenberger S (1989) Coastal resource management in a clam shell. In: Circum-Pacific Prehistory Conference Reprint Proceedings III: development of hunting-fishing-gathering maritime societies on the Pacific. Washington State University, Pullman

Daniels PS (2009) A gendered model of resource depression: a case study on the Northwest Coast of North America. PHD Thesis. University of Washington Press, Seattle

De Laguna F (1972) Under Mount Saint Elias: the history and culture of the Yakutat Tlingit, Smithsonian Contributions to Anthropology, vol 7. Smithsonian Institution, Washington DC

Deur DE, Turner NJ (2005) Introduction: reconstructing indigenous resource management, reconstructing the history of an idea. In: Deur DE, Turner NJ (eds) Keeping it living: traditions of plant use and cultivation on the northwest coast of North America. University of Washington Press, Seattle

Donald L (1997) Aboriginal slavery on the northwest coast of North America. University of California Press, Berkeley

Drucker P (1951) The northern and central Nootkan tribes, Smithsonian Institution Bureau of American Ethnology Bulletin 144. United States Government Printing Office, Washington DC

Drucker P (1955) Indians of the northwest coast. American Museum Science Books, Natural History Press, Garden City

Duff W (1952) The Upper Stalo Indians, anthropology in British Columbia, memoir no. 1. British Columbia Provincial Museum, Victoria

Easton NA (1985) The underwater archaeology of Straits Salish reef-netting University of Victoria, Victoria, M.A. Thesis

Easton NA (1990) The archaeology of Straits Salish reef netting: past and future research strategies. NW Anthropol Res Notes 24(2):161-177

Ellis DW, Swan L (1981) Teaching of the tides: uses of marine invertebrates by the Manhousat people. Theytus Books, Nanaimo

Ellis DW, Wilson S (1981) The knowledge and usage of marine invertebrates by the Skidegate Haida people of the Queen Charlotte Islands, monograph series 1. The Queen Charlotte Islands Museum. Society, Skidegate

Elmendorf WW (1992) The structure of Twana culture. WSU Press reprint series, Washington State University Press, Pullman
Ford R (1985) Patterns of prehistoric food production in North America. In: Ford $R$ (ed) Prehistoric food production in North America. Museum of Anthropology, Anthropological Paper no 75, University of Michigan, Ann Arbor

Fowler CS, Lepofsky D (2011) Traditional resource and environmental management. In: Anderson EN, Pearsall DM, Hunn ES, Turner NJ (eds) Ethnobiology. Wiley-Blackwell, Hoboken

Gould RA (1968) Seagoing canoes among the indians of northwestern California. Ethnohistory 15(1):11-42

Groesbeck A (2013) Ancient clam gardens enhance shellfish production; implications for contemporary coastal conservation and management. Masters Thesis. Simon Fraser University, Burnaby, BC

Gunther $E$ (1926) An analysis of the first salmon ceremony. Am Anthropol 28(4):605-617

Gunther E (1927) Klallam ethnography. UW Pubs Anthropol 1(5):171-314

Gunther $E$ (1928) A further analysis of the first salmon ceremony. UW Pubs Anthropol 2(5):129-173

Haeberlin H, Gunther E (1930) The indians of Puget Sound. UW Pubs Anthropol $4(1): 1-84$

Haggan N, Turner N, Carpenter J, Jones JT, Mackie Q, Menzies C (2006) 12,000+ years of change: linking traditional and modern ecosystem science in the Pacific Northwest. University of British Columbia Fisheries Centre Working Paper \#2006-02. University of British Columbia, Vancouver

Hamori-Torok C (1990) Haisla. In: Suttles W (ed) Handbook of North American Indians, vol 7, Northwest Coast. Smithsonian Institution, Washington DC, pp 306-311

Harper JR, Haggarty J, Morris MC (1995) Final report, Broughton Archipelago clam terrace survey. Land Use Coordination Office, BC Ministry of Government Services, Victoria

Harper JR, Haggerty J, Morris MC (2003) Broughton Archipelago: clam terrace survey, Coastal and Ocean Resources, Sidney. British Columbia, Land Use Coordination Office, BC Ministry of Government Services, Victoria

Harris DR (1989) Foraging and farming: the evolution of plant exploitation. Unwin Hyman, London

Harris DR (1996) The interplay of enthographic and archaeological knowledge in the study of past human subsistence in the tropics. J R Anthropol Inst 12:s63-s78

Hunn EW, Johnson D, Russell P, Thornton TF (2003) Huna Tlingit traditional environmental knowledge, conservation, and the management of a "wilderness" park. Curr Anthropol 44:S79-S103

Johannes RE (1981) Working with fishermen to improve coastal tropical fisheries and resource management. Bull Marine Sci 31(3):673-680

Johannes RE (1982) Traditional conservation methods and protected marine areas in Oceania. Ambio 11(5):258-261

Jones JT (2002) "We looked after all the salmon streams": traditional Heiltsuk cultural stewardship of salmon and salmon streams: a preliminary assessment. University of Victoria, Victoria, M.A. Thesis

Kennedy D, Bouchard R (1983) Sliammon life. Sliammon lands, Talonbooks, Vancouver

Kennedy DID, Bouchard RT (1990) Bella Coola. In: Suttles W (ed) Handbook of North American Indians, vol 7, Northwest Coast. Smithsonian Institution, Washington DC, pp 323-339

Langdon SJ (2006a) Tidal pulse fishing: selective traditional Tlingit salmon fishing techniques on the west coast of the Prince of Wales Archipelago. In: Menzies CR (ed) Traditional ecological knowledge and natural resource management. University of Nebraska Press, Lincoln

Langdon SJ (2006b) Traditional knowledge and harvesting of salmon by Huna and Hinyaa Tlingit, final report (project no. 02-104). U.S. Fish and Wildlife Service, Office of Subsistence Management. Fisheries Resource Monitoring Program, Anchorage

Lepofsky D (2005) Marshall's Beach fish trap, Lasqueti Island. The Midden 37(1):10-11

Lepofsky D, Deur D (2011) "Managing Intertidal Ecosystems on the Northwest Coast" a Case Study In Traditional Resource and Environmental Management, by CS Fowler and D Lepofsky. In Ethnobiology, Anderson EN, Pearsall DM, Hunn EW, Turner NJ (eds), pp. 285-304, Wiley-Blackwell, Hoboken

Lepofsky D, Kahn J (2011) Cultivating an ecological and social balance: elite demands and commoner knowledge in ancient Maohi agriculture, Society Islands. Am Anthropol 113(3):319-335

Lepofsky D, Trost T, Morin J (2007) Coast Salish interaction: a view from the inlets. Can J Arch 31:190-223 
Lertzman K (2009) The paradigm of management, management systems, and resource stewardship. J Ethnobio 29(2):339-358

Losey R (2010) Animism as a means of exploring archaeological fishing structures on Willapa Bay, Washington, USA. Cambridge Arch J 20(1):17-32

Losey RJ, Yamada S, Largaespada L (2004) Late-Holocene dungeness crab (Cancer magister) harvest at an Oregon coast estuary. J Arch Sci 31:1603-1612

Lyman RL (2003) Pinniped behavior, foraging theory, and the depression of metapopulations and nondepression of a local population on the southern Northwest Coast of North America. J Anthropol Archael 22:376-388

McKechnie I (2005) Five thousand years of fishing at a shell midden in the Broken Group Islands. Thesis, Simon Fraser University, Burnaby, BC, Barkley Sound. M.A

McKechnie I (2007) Investigating the complexities of sustainable fishing at a prehistoric village on western Vancouver Island, British Columbia Canada. Nat Cons 15:208-222

Miller J, Seaburg WR (1990) Athapaskans of Southweatern Oregon. In: Suttles W (ed) Handbook of North American Indians, vol 7, Northwest Coast. Smithsonian Institution, Washington, pp 580-588

Monks GG (1987) Prey as bait: the Deep Bay example. Can J Archaeol 11:119-142

Monks GG (2011) Local optimization and faunal remains in Northern Barkley Sound, Western Vancouver Island, British Columbia. In: Moss ML, Cannon A (eds) The archaeology of North Pacific fisheries. University of Alaska Press, Fairbanks

Moore CD, Mason AR (2011) Demonstration survey of prehistoric reef-net sites with sidescan sonar, near Becher Bay, British Columbia, Canada. Int J Nautical Archaeol. doi:10.1111/j.1095-9270.2011.00324.x

Moss ML (1993) Shellfish, gender, and status on the northwest coast: reconciling archaeological, ethnographic, and ethnohistorical records of the Tlingit. Am Anthropol 95:631-652

Munsell DA (1976) The Wapato Creek Fish weir site 45PI47 Tacoma, Washington. In: Croes DR (ed) The excavation of water-saturated archaeological sites (wet sites) on the northwest coast of North America, National Museum of Man Mercury Series, Archaeological Survey of Canada, paper no 50. National Museums of Canada, Ottawa

Newton RG, Moss ML (2005) Haa Atxaayi Haa Kusteeyix Sitee, our food is our Tlingit way of life: excerpts of oral interviews. USDA Forest Service, Alaska Region, R10-MR-30, Juneau

Orchard TJ (2007) Otters and urchins: continuity and change in Haida economy during the Late Holocene and maritime fur trade periods. PhD Thesis. University of Toronto, Toronto

Pierson N (2011) Bridging troubled waters: zooarchaeology and marine conservation on Burrard Inlet. Simon Fraser University, Burnaby, BC, M.A. Thesis

Powell M (2012) Divided waters: Heiltsuk spatial management of herring fisheries and the politics of native sovereignty. West Hist Q 43:489-510

Ramos J, Mason R (2004) Traditional ecological knowledge of Tlingit people concerning the sockeye salmon fishery of the Dry Bay Area. A cooperative agreement between Department of the Interior National Park Service and the Yakutat Tlingit Tribe. Final report (fis) project 01-091. National Park Service, Yakutat, Alaska

Reo NJ (2011) The importance of belief systems in traditional ecological knowledge initiatives. Int Indigenous Pol J 2(4), http://ir.lib.uwo.ca/iipj/vol2/iss4/8

Reo NJ, Whyte KP (2011) Hunting and morality as elements of traditional ecological knowledge. Hum Ecol. doi:10.1007/s10745-011-9448-1

Rozen D (1981) Underwater archaeology at Point Roberts, Washington. The Midden 13(1):9-10

Schalk RF (1977) The structure of an anadromous fish resource. In: Binford LR (ed) For theory building in archaeology: essays on faunal remains, aquatic resources, and systematic modeling. Academic Press, New York

Siemthlut Washington M (2004) Reflecting on traditional governance. Sliammon Treaty Society, Powell River, BC

Smith BD (2001) Low-level food production. J Archaeol Res 9(1):1-43

Smith BD (2011a) General patterns of niche construction and the management of 'wild' plant and animal resources by small-scale pre-industrial societies. Phil Trans R Soc Bio 366:836-848

Smith BD (2011b) A cultural niche construction theory of initial domestication. Biol Theory 6(3):260-271

Sproat GM (1868) The Nootka: scenes and studies of savage life. Smith, Elder and Co, London
Stern BJ (1934) The Lummi Indians of Northwest Washington. Columbia University Press, New York

Stewart H (1977) Indian fishing: early methods on the northwest coast. J.J. Douglas, Vancouver

Suttles W (1955) Katzie ethnographic notes. Anthropology in British Columbia, memoir no. 2. British Columbia Provincial Museum, Victoria

Suttles W (1974) Coast Salish and western Washington Indians: the economic life of the Coast Salish of Haro and Rosario Straits. Garland, New York

Suttles W (1987) Coping with abundance: subsistence on the Northwest Coast. In: Suttles W (ed) Coast Salish essays. University of Washington Press, Seattle

Swezey SL, Heizer RF (1977) Ritual management of salmonid resources in California. J Cali Anthropol 4:6-29

Szpak P, Orchard TJ, McKechnie I, Gröcke DR (2012) Historical ecology of late Holocene sea otters (Enhydra lutris) from British Columbia: isotopic and zooarchaeological perspectives. J Arch Sci 36(12):2734-2741

Thornton TF (1999) Tleikw Aaní, the berried landscape: the structure of Tlingit edible fruit resources in Glacier Bay, Alaska. J Ethnobiol 19(1):27-48

Thornton TF (2012) Watersheds and marinescapes: understanding and maintaining cultural diversity among southeast Alaska natives. In: Johnston BR, Hiwasaki L, Klaver IJ, Castillo AR, Strang V (eds) Water, cultural diversity, and global environmental change. Springer, Berlin. doi:10.1007/978-94-007$1774-9-9$

Thornton TF, Scheer AM (2012) Collaborative engagement of local and traditional knowledge and science in marine environments: a review. Ecol Soc 17(3):8, 10.5751/ES-04714-170308

Thornton TF, Butler V, Funk F, Moss M, Hebert J, Elder T (2010a) Herring synthesis: documenting and modeling herring spawning areas within socio-ecological systems over time in southeastern Gulf of Alaska. North Pacific Research Board project \#728

Thornton TF, Moss ML, Butler VL, Heber J, Funk F (2010b) Local and traditional knowledge and the historical ecology of Pacific herring in Alaska. J Econ Anthropol 14(1):81-88

Turner NJ (2005) The Earth's blanket: traditional teachings for sustainable living. Douglas \& McIntyre, Vancouver

Turner NJ, Berkes F (2006) Coming to understanding: developing conservation through incremental learning in the Pacific northwest. Hum Ecol 34:495-513

Turner NJ, Jones JT (2000) "Occupying the land": traditional patterns of land and resource ownership among First Peoples of British Columbia. CD ROM Proceedings. IASCP 2000 (Common Property Resources) conference, Bloomington, Indiana

Turner NJ, Ignace MB, Ignace R (2000) Traditional ecological knowledge and wisdom of aboriginal peoples in British Columbia. Ecol Appl 10(5):1275-1287

Turner NJ, Recalma-Clutesi K, Deur D (2013) Back to the clam gardens., http:// blog.ecotrust.org/inside-the-clam-gardens-a-source-of-coastal-sustenance/

Ubelaker DH (2006) Population size, contact to nadir. In: Ubelaker DH (ed) Environment, origins, and population, vol 3. Smithsonian Institution, Washington DC

Weiser A, Lepofsky D (2009) Ancient land use and management of Ebey's Prairie, Whidbey Island, Washington. J Ethnobio 29(2):184-212

White E (2011) Heiltsuk stone fish traps on the central coast of British Columbia. In: Moss ML, Cannon A (eds) The archaeology of north Pacific fisheries. University of Alaska Press, Fairbanks

White EAF, White EAF X (2006) Heiltsuk stone fish traps: products of my ancestors' labour. M.A. Thesis. Simon Fraser University, Burnaby, BC

Wigen RJ (2005) History of the vertebrate fauna in Haida Gwaii. In: Fedje DW, Mathewes RW (eds) Haida Gwaii: human history and environment from the Time of the Loon to the Time of the Iron People. UBC Press, Vancouver

Williams J (2006) Clam gardens: aboriginal mariculture on Canada's west coast. New Star Books, Vancouver

Woods DJ, Woods D (2005) Ancient sea gardens. Mystery of the Pacific northwest. Aquaculture Pictures, Toronto

doi:10.1186/2192-1709-2-12

Cite this article as: Lepofsky and Caldwell: Indigenous marine resource management on the Northwest Coast of North America. Ecological Processes 2013 2:12 